\title{
Embodied Energy and Embodied Carbon in Different Industrialized Structural Systems Scenarios of a Prototype Building
}

Lizeth Rodríguez ${ }^{1}$ | José María González ${ }^{2}$ | Oriol París ${ }^{3}$ | Adrián Muros ${ }^{4}$

Received: 2021-03-30 | Last version: 2021-07-29

Abstract

\begin{abstract}
A design optimization strategy for the embodied impacts reduction, is to consider a industrialized prefabrication techniques according to the type of building, insomuch as design process take acount a disassembly system, it would be decreese the waste, raw material, therefore the embodied impacts. This work aims to obtain the results of environmental impacts, characterized in two types of impacts considered relevant in the construction industry, based on the principle of energy conservation, these impacts are: Embodied Energy and Embodied Carbon (CO2 equivalent), in the manufacture and transport of seven versions of pre-sized structural models with industrialized construction systems, for the same prototype building, as well as, check the variables that affect the selection of a construction system at an early stage of design. The structural preliminary draft, along with the predimensioned considering only the gravitational loads, is a representative sample for an evaluation and decision-making in the early stages of a project, which lead the design team to consider hybrid industrialized manufacturing systems, between open and closed, or between prefabricated and in-situ systems, in order to avoid envioronmental impacts.
\end{abstract}

Key words: Emissions; prefabricated build; environmental impacts; carbon footprint

Citación

Rodríguez, L et al., Embodied Energy and Embodied Carbon in Different Industrialized Structural Systems Scenarios of a Prototype Building. ACE: Architecture, City and Environment, 16(47), 10454. DOI: http://dx.doi.org/10.5821/ace.16.47.10454

\section{Energía incorporada y carbono incorporado en diferentes escenarios de sistemas estructurales industrializados de un edificio prototipo}

Resumen

\begin{abstract}
Una estrategia de optimización a considerar en el diseño, para la reducción de impactos incorporados, es la construcción con técnicas de prefabricación industrializada, según el tipo de edificio. Este trabajo tiene como objetivo obtener los resultados de impactos ambientales caracterizados en dos tipos de impactos considerados relevantes en la industria de la construcción, con base en el principio de conservación de energía, estos impactos son: Energía Incorporada y Carbono Incorporado ( $\mathrm{CO}^{2}$ equivalente), en la fabricación y transporte de siete versiones de modelos estructurales predimensionados con sistemas constructivos industrializados, para un mismo edificio prototipo, así como comprobar las variables que inciden en la selección de un sistema constructivo en una etapa inicial de diseño. El anteproyecto estructural y predimensionado frente a cargas gravitatorias, es una muestra representativa para una evaluación y toma de decisiones en las primeras etapas de un proyecto, que llevan a un equipo de diseño a considerar sistemas híbridos entre manufactura industrializada; abierta o cerrada y entre sistemas prefabricados o sistemas in situ, con el fin de evitar impactos ambientales.
\end{abstract}

Palabras clave: Emisiones; construcción prefabricada; impactos ambientales; huella de carbono

${ }^{1}$ M. I. Architect, Lecturer Researcher at Spatial Organization Department, Central America University, UCA, El Salvador (ORCiD: 0000-0003-2890-0433), ${ }^{2}$ Ph.D., Architect, Professor at Department of Architectural Technology, School of Architecture of Barcelona, ETSAB, UPC (ORCiD: 0000-0001-6692-1919), ${ }^{3}$ Ph.D., Architect, Professor at Department of Architectural Technology, School of Architecture of Barcelona, ETSAB, UPC (ORCiD: 0000-0003-2593-980X, ${ }^{4}$ Ph.D., Architect, Professor at Department of Architectural Technology, School of Architecture of Barcelona, ETSAB, UPC (ORCID ID: 0000-0002-0167-2904). Contact e-mail: Irrodriguez@uca.edu.sv 


\section{Introduction}

Avoiding environmental impacts on the construction sector is one of the challenges posed in governance agendas, this is reflected in laws, regulations, codes, standards and manuals. The triggering event for this global phenomenon has been the Kyoto Protocol in which nations pledged to reduce greenhouse gas emissions, through strategies aimed at combating emissions causes, two of these causes contributing to global warming are linked to buildings, one is waste generation and the other is the use of non-renewable resources and burning fossil fuels (Comunidad Autónoma de Cataluña, 2017).

The construction sector accounts for almost $40 \%$ of global energy consumption, 30\% of raw material use, $25 \%$ of solid waste, $25 \%$ of water use, $12 \%$ of land use and $33 \%$ of global greenhouse gas-related emissions (Chau, Leung, \& Ng, 2015) (Eberhardt, Birgisdóttir, \& Birkved, 2019).

The most important action that nations have taken is to generate mandatory compliance instructions for the evaluation and development of building projects at all stages; planning, design, construction, rehabilitation and disassembly. In this sense, the duty of a designer is to account for potential environmental impacts and evaluate scenarios at the project stages (AENOR, 2006a) To this end, tools and databases have been created to help professionals linked to the building sector generate better development alternatives and to check the impacts generated by their design decisions, as well as the industry has a duty to incorporate information on the emissions of its production processes into the certification of its products (AENOR, 2014) (Rossi, Marique, Glaumann, \& Reiter, 2012).

Thus, Life Cycle Assessment, LCA is an internationally accepted methodology for assessing the environmental impacts caused by building materials. The methodology described in ISO-14044 or its UNE equivalent (AENOR, 2006b) (Hollberg, Genova, \& Habert, 2020).

The World Council Society of Environmental Toxicology and Chemistry SETAC (2002), indicates that the LCA is an objective process for assessing the environmental loads associated with a product, process or activity and provides for the following functions:

a. Identifying and quantifying the use of matter, energy and discharges into the environment.

b. Determining the impact that resource use and discharges have on the environment.

c. Implementing environmental improvement strategies.

An LCA includes the complete cycle of a product, process or activity, considering the stages of:

a. Extraction, and processing of raw materials.

b. Production, transport and distribution.

c. Use, reuse, maintenance, recycling and disposal of waste.

In a more pragmatic area, the European Commission in 2017 publishes a report named Science for Policy, through the Joint Research Centre called Level(s) which is the EU's common framework of basic sustainability indicators for residential and office buildings (European Commission, 2021). The report identifies at which stage of a construction project it can be used:

a. Design phase, based on calculations, simulations, and scenarios.

b. Execution phase, fundamented on plans based on construction, specifications and tracking.

c. Completion phase, based on commissioning and testing.

d. Operating phase.

On the other hand, in terms of sustainability, the scales of regulation range from the international, regional and local levels, in this regard at the international level the International EPD System is a comprehensive programme governed by the United Nations, for type III environmental declarations

ACE, 16 (4.7) CC BY-ND 3.0 ES | UPC Barcelona, España | Embodied Energy and Embodied Carbon in Different Industrialized Structural Systems Scenarios of a Prototype Building. DOI: http://dx.doi.org/10.5821/ace.16.47.10454 
operating in accordance with ISO 14025. An EPD is the environmental declaration of products that present transparent, verified and comparable information about the environmental impact of products on the lifecycle.

However, other authors believe that, although the LCA methodology is widely used, it has not yet been leveraged as an eco-design tool to inform users about the relative importance of the environmental impact of building components, sizing options, construction shapes and design parameters. On the other hand, knowledge of the calculation of the embodied impacts of building elements shows options in design decision-making, for example; about which material and thickness achieve the largest reductions in impacts incorporated. In the same line, the results of a study show that the built-in impact calculation method can help significantly reduce the carbon footprint in the building elements, leading the design to optimization (Flager, Lepech, \& Fischer, 2013).

A design optimization strategy for the reduction of embodied impacts is a type of construction with industrialized prefabrication techniques, according to the type of building, so will the reduction of impacts, as indicated by a comparative study between schools be built with conventional and industrialized systems, showing up to $60 \%$ energy savings, waste reduction and reduction in the carbon footprint (Pons \& Wadel, 2011).

The origin of industrialized construction dates back to the years after the Second World War, because the reconstruction of cities demanded efficient strategies for the construction of homes, one of these was the prefabrication of serial elements (Chemillier, 1980).

Nowadays industrialized construction systems can be of an open or a closed type, either in the entire building or in one of its elements. In the case of closed systems, each element is coincident with another, provided with compatibility with each other. In contrast to these, open systems are characterized by being standard and provide design flexibility, but require special attention to joints (Albus, 2017) (Albus, 2018). Table 1 shows the typological universe of the most common industrialized prefabrication construction systems in Europe.

Table 1. Industrialized prefabrication systems

\begin{tabular}{llll}
\hline \multicolumn{1}{c}{ Structural system } & \multicolumn{1}{c}{ Concrete } & \multicolumn{1}{c}{ Steel } & Wood \\
\hline Frames & Precast concrete frames & Rolled steel frames & Laminated wood frames \\
$\begin{array}{ll}\text { Structural wall } \\
\text { (bearing walls) }\end{array}$ & $\begin{array}{l}\text { Precast concrete load- } \\
\text { bearing walls and Precast } \\
\text { concrete load-bearing } \\
\text { facades or semi-module }\end{array}$ & Steel-frame walls & $\begin{array}{l}\text { CLT panels and Balloon- } \\
\text { frame walls }\end{array}$ \\
$\begin{array}{lll}\text { Self-supporting 3D } \\
\text { modules }\end{array}$ & $\begin{array}{l}\text { Precast concrete 3D modules } \\
\text { Source: Own ellaboration }\end{array}$ & $\begin{array}{l}\text { Steel-frame 3D } \\
\text { modules }\end{array}$ & Balloon-frame 3D modules \\
\end{tabular}

To expand this optics, this work aims to obtain the results of environmental impacts characterized in 2 types of impacts considered relevant in the construction industry, given the flow of energy along the supply chain based on the principle of energy conservation (G. P. Hammond \& Jones, 2008), which for purposes of this analysis will be the embodied energy in the construction materials, these impacts are: Embodied Energy and Embodied Carbon ( $\mathrm{CO}_{2}$ equivalent), in the manufacture and transport of seven versions of pre-sized structural models with industrialized construction systems, for the same prototype building, as well as check the variables that affect the selection of a construction system at an early stage of design. Other specific objectives are:

1. Identify environmental impacts and contrast impacts with the performance of each industrialized construction system. 
2. Develop comparative analysis tools between construction systems to verify the relationship between environmental impacts and the consequences of selecting a particular construction and structural system.

3. Check the adaptations that an architectural project entails according to the selected construction and structural system.

4. Review the field of industrialized construction.

\section{Methodology}

The study is addressed from three points of view: Industrialized construction and prefabrication, structural development, sustainability parameters.

In order to build the common thread between the three themes, the investigative question is asked: What is the binding element between the themes of construction, structure and sustainability? To answer this question, a methodological scheme has been developed as shown in Figure 1 detailing the phases of work and specifying the results that underpin the previous phase:

Figure 1. Methodological Scheme
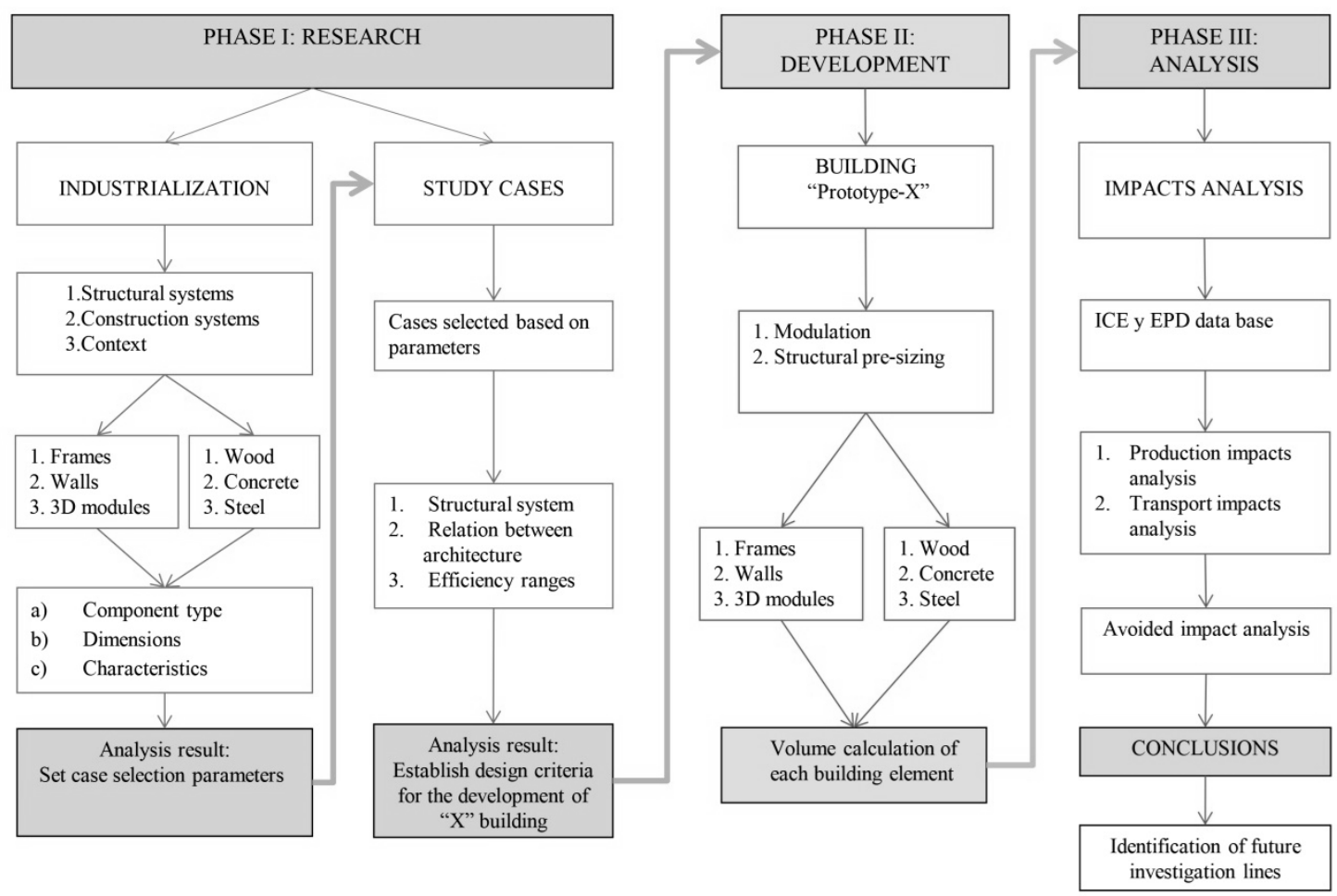

Source: Own ellaboration

\subsection{Phase 1: Research benchmark}

In the research benchmark phase, the relationship between structural systems is established according to the characterization of the construction systems, they are exemplified through case studies that have been selected by their geographical location in Spain as an outstanding example of the application of construction technologies of industrialized prefabrication.

ACE, 16 (4.7) CC BY-ND 3.0 ES | UPC Barcelona, España | Embodied Energy and Embodied Carbon in Different Industrialized Structural Systems Scenarios of a Prototype Building. DOI: http://dx.doi.org/10.5821/ace.16.47.10454 
In this area, the Spanish Technical Association of Prestressing ATEP, by its initials in Spanish, indicate all construction systems have their own characteristics, considering their facets, design, height considerations, joining details and stability. It also recommends that the joints between elements be as simple as possible and that the building as a whole be analyzed avoiding doing so as if it were a conventional system in situ, while paying attention to the reasons for possible local failure and the elements of stability according to structural typologies (Asociación Técnica Española del Pretensado (FIP-ATEP), 1996), as a Table 2 shows.

Table 2. Stabilizing elements according to structural system

\begin{tabular}{|c|c|c|c|c|c|}
\hline Stabilizer element & Frames & Skeleton & $\begin{array}{c}\text { Structural } \\
\text { walls }\end{array}$ & $\begin{array}{l}\text { Bearing } \\
\text { facade }\end{array}$ & $\begin{array}{l}\text { Self-supporting } \\
\text { 3D modules }\end{array}$ \\
\hline Corbel column & $x$ & $x$ & & & \\
\hline Bending moment resistant connections & $x$ & & & & \\
\hline Slab as a diaphragm & $x$ & $x$ & $x$ & $x$ & \\
\hline Bracing & $x$ & $x$ & & & \\
\hline Shear-resistant walls & & $x$ & $x$ & $x$ & \\
\hline Central core & & $\mathrm{x}$ & $x$ & $x$ & \\
\hline Self-supporting blocks & & & & & $x$ \\
\hline
\end{tabular}

Source: Own ellaboration

The selection of construction systems for both the search for references and for the development of the prototype building was carried out on the basis of the following criteria:

1. At least two constructive typologies were considered for each structural system (Table 1).

2. Open industrialized prefabrication technologies were selected.

3. The components are manufactured at a distance of no more than $1000 \mathrm{~km}$ from the reference location, Barcelona, with the exception of case 1 that was considered to be a pioneer in Latin America.

There is special interest in 4-storey case studies, with the purpose of verifying the minimum existence of structural stabilizing elements defined in Table 2. The case studies analyzed were:

1. Facade of Concrete: Secretariat of the Administrative Center of Bahia in Salvador Bahia, Brazil (1973). Designed by Joao Filgueiras Lima, "Lelé".

2. Prefabricated concrete frame: Group of 112 social homes in the neighborhood "El Polvorín" in Barcelona, Spain (2005). Designed by Pich Architects.

3. Structural walls of CLT wood: The housing cooperative La Borda in industrial enclosure of Can Batlló Barcelona, Spain (2018). Designed by Lacol Cooperative of Architects.

4. 3D prefabricated concrete modules: The building of 30 official protection homes VPO endowments for young people in Banyoles promoted by INCASOL in Girona, Spain (2017). Designed by Xavier Tragant and Miguel Morte.

The common factor in the four case studies was the speed in the execution of building, in less than a year. Regularity in the design and do without braceing were related structural characteristics. Energy savings, the reduction of waste, were the characteristics sought in the four case studies too.

\subsection{Phase II: Development of prototype building}

A building proposal is developed, with regularity on the floor and elevation as a prototype building vision called a "prototype-X", taking attributes from the analyzed case studies. Likewise, the modulation and calculation of pre-dimensioning is developed for three structural typologies considering three construction systems; Concrete, Steel and Wood, resulting in seven versions of the "prototype-X" building, without detailing the connecting elements, but it does highlight the system

ACE, 16 (4.7) CC BY-ND 3.0 ES | UPC Barcelona, España | Embodied Energy and Embodied Carbon in Different Industrialized Structural Systems Scenarios of a Prototype Building. DOI: http://dx.doi.org/10.5821/ace.16.47.10454 
resistant only to gravitational load and in this way, to confirm the weight of the elements, which is the basis for analysis.

The "prototype-X" building is the basis for structural development in seven combinations of structural systems representative of the typologies mentioned in Table 1 that subscribes to an area of $25 \mathrm{~m} x$ $25 \mathrm{~m}$ and can potentially accommodate between six and eight housing units per floor with a single stair and elevator core, thus optimizing both vertical and horizontal circulations, without contemplating the distribution on the floor of the houses. The $25 \mathrm{~m}$ dimension responds to divide this amount by 3 and 4, resulting in $6.3 \mathrm{~m}$ and $8.3 \mathrm{~m}$ which is optimal range separation perpendicular to the load direction of prefabricated systems, especially concrete frames, considering that this industrialized system is the most common in Spain.

Another criterion of development of the "prototype-X" building is plant symmetry and both vertical and horizontal regularity. In this same line, we have sought to distribute the vertical resistant elements symmetrically, with the objective that the geometric center matches the center of rigidity, to avoid torsion, see Figure 2 and Table 3.

Figure 2. "prototype-X” Building plan
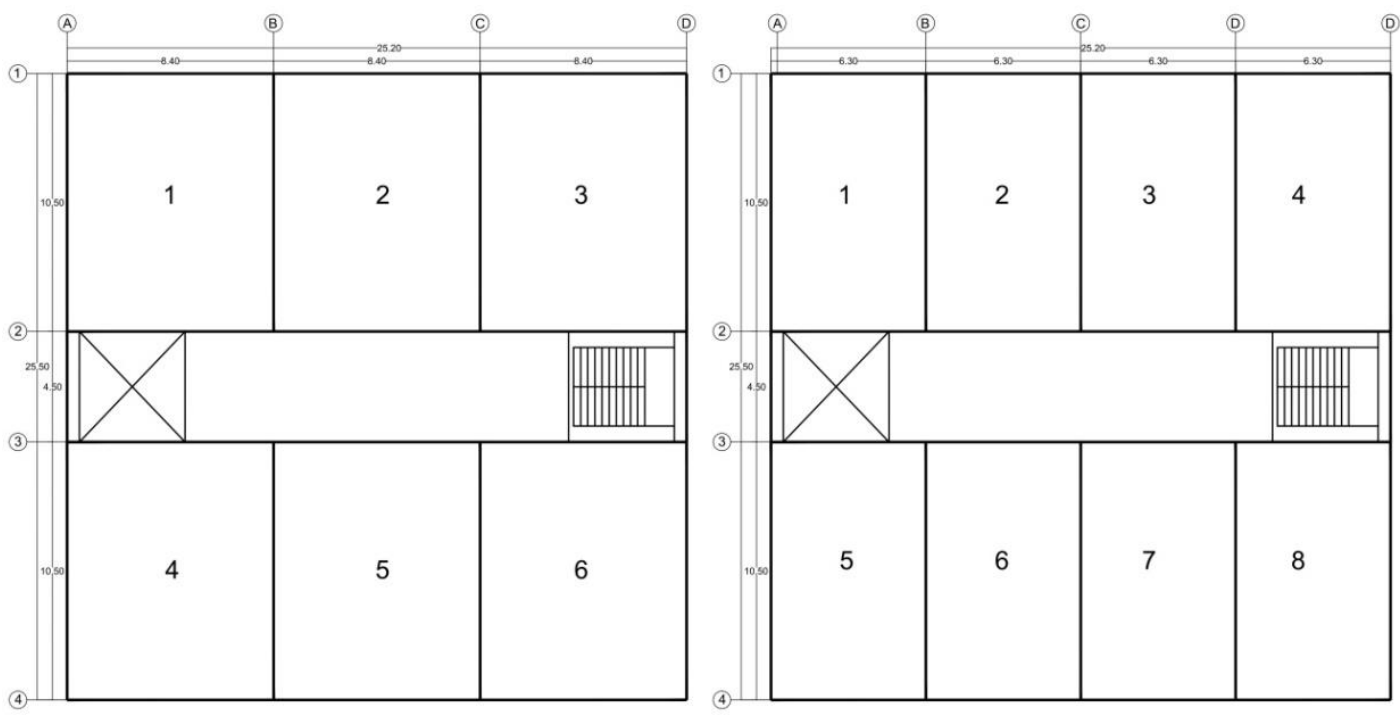

Source: Own ellaboration

Table 3. Structural system elements and enveloping

\begin{tabular}{|c|c|c|c|c|c|}
\hline $\begin{array}{l}\text { Structural } \\
\text { system }\end{array}$ & Building & resistant & $\begin{array}{l}\text { Horizontal } \\
\text { resistant element }\end{array}$ & Slab & $\begin{array}{l}\text { Facade not load- } \\
\text { bearing }\end{array}$ \\
\hline Frames & $\begin{array}{l}1-F-C \\
2-F-S\end{array}$ & $\begin{array}{l}\text { Precast concrete } \\
\text { column } \\
\text { Rolled steel column } \\
\text { HEB }\end{array}$ & $\begin{array}{l}\text { Precast concrete } \\
\text { beam } \\
\text { Rolled steel beam } \\
\text { IPE }\end{array}$ & $\begin{array}{l}\text { Alveolar } \\
\text { plate slabs } \\
\text { Steel die cut } \\
\text { sheet }\end{array}$ & $\begin{array}{l}\text { Precast concrete } \\
\text { facade } \\
\text { Precast concrete } \\
\text { facade }\end{array}$ \\
\hline $\begin{array}{l}\text { Structural } \\
\text { walls }\end{array}$ & $\begin{array}{l}3-W-C \\
4-W-W\end{array}$ & $\begin{array}{l}\text { Precast concrete } \\
\text { load-bearing walls } \\
\text { CLT wood load- } \\
\text { bearing walls }\end{array}$ & & $\begin{array}{l}\text { Alveolar } \\
\text { plate slabs } \\
\text { CLT wood } \\
\text { panel }\end{array}$ & \\
\hline Hybrid mixed & 5-MIX-C & $\begin{array}{l}\text { Precast concrete Self- } \\
\text { supporting 3D module }\end{array}$ & & $\begin{array}{l}\text { Alveolar } \\
\text { plate slabs }\end{array}$ & \\
\hline $\begin{array}{l}\text { Self- } \\
\text { supporting } \\
\text { 3D modules }\end{array}$ & $\begin{array}{l}6-3 D-C \\
7-3 D-W\end{array}$ & $\begin{array}{l}\text { Precast concrete self- } \\
\text { supporting 3D module } \\
\text { CLT wood self- } \\
\text { supporting 3D module }\end{array}$ & & & \\
\hline
\end{tabular}

Source: Own ellaboration

ACE, 16 (4.7) CC BY-ND 3.0 ES | UPC Barcelona, España | Embodied Energy and Embodied Carbon in Different Industrialized Structural Systems Scenarios of a Prototype Building. DOI: http://dx.doi.org/10.5821/ace.16.47.10454 
Taking into account the conditions of the Basic Structural Security Document of the Technical Building Code CTE-DB-SE (Ministerio de Fomento, 2009c) this analysis has made the following simplification in the structural systems that will be subject to comparative analysis:

1. Partial safety coefficients for loads and materials characteristics as well as concurrency coefficients for loads are established.

2. The combinations of Ultimate Limit State (ULS) and Serviceability Limit State (SLS) for actions, CTE-DB-SE-AE (Ministerio de Fomento, 2009a), CTE-DB-SE-A (Ministerio de Fomento, 2007a), CTE-DB-SE-C (Ministerio de Fomento, 2007b), CTE-DB-SE-M (Ministerio de Fomento, 2009b), are generated.

3. Gravitational loads are set: Permanent load G and Usage overload Q and N (no side thrust load is considered).

4. The combined load scenarios are set and the most unfavorable one is selected.

5. The process is performed in reverse to the sizing check with the ULS, that is, the dimensional unknown is generated in the equation that relates the design resistance to that of the code, depending on the system, concrete, steel, wood and according to the efforts of the elements: Axial, Bending, Shear and Deformation (this value relates to SLS).

6. Depending on the industrial manufacturer, the dimensions of structural elements, equal to or greater than those of pre-dimensioning, are selected. See Table 4.

\subsection{Phase III: Analysis of environmental parameters}

Taking into account the ICE Inventory of Carbon and Energy database (G. Hammond, Jones, Lowrie, \& Tse, 2011) develops the calculation of environmental impacts; Embodied Energy and Embodied Carbon ( $\mathrm{CO}_{2}$ equivalent), by manufacturing and transporting the seven presized buildings, as well as analyzes the results comparatively and establishes conceptual and measurable parameters to estimate the potential to avoid impacts.

In this case, LCA is not performed at the end of the cycle, but an environmental load analysis is estimated by manufacturing and transport, under a Cradle to Gate approach that counts environmental loads from the source of raw materials to the factory door according to two ICE indicators.

The subject of analysis is the "prototype-X" building in its seven versions, and to perform the comparative scenarios of environmental impacts the data source is required to be homogeneous and representative, in this case it is established as a baseline, the Inventory of Carbon and Energy (ICE) Version 2.0 data produced by Prof. Geoff Hammond and Craig Jones, from the Department of Mechanical Engineering, Bath University, United Kingdom, has also been contrasted with data from the following sources that are nurtured by industry reports:

- Institute of Construction Technology of Catalonia

- The International EPD System

. EU ECO Platform EPD

- Global Declarations EPD AENOR

- Construction Programme DAP, Sustainable Construction Agenda.

ACE, 16 (4.7) CC BY-ND 3.0 ES | UPC Barcelona, España | Embodied Energy and Embodied Carbon in Different Industrialized Structural Systems Scenarios of a Prototype Building. DOI: http://dx.doi.org/10.5821/ace.16.47.10454 
Table 4. Pre-sizing

\begin{tabular}{|c|c|}
\hline 1-P-H & \\
\hline Elements & Dimensions (cm) \\
\hline Column with corbel. & $50 \times 50$ \\
\hline Beams T y $L$ & $50 \times(40+25)$ \\
\hline $\begin{array}{l}\text { Alveolar plate slabs + } \\
\text { compression layer } \\
\text { Footing }\end{array}$ & $\begin{array}{l}(25+5) \times 120 \times \text { Length } \\
250 \times 250 \times 50\end{array}$ \\
\hline \multicolumn{2}{|l|}{ 2-P-A } \\
\hline Elements & Dimensions (cm) \\
\hline Column HEB 400 & $30 \times 40$ \\
\hline Beam IPE 500 & $20 \times 50$ \\
\hline $\begin{array}{l}\text { Steel die cut sheet + } \\
\text { compression layer } \\
\text { Footing }\end{array}$ & $\begin{array}{l}14 \times 88 \times 0.08 \\
240 \times 240 \times 50\end{array}$ \\
\hline \multicolumn{2}{|l|}{ 3-M-H } \\
\hline Elements & Dimensions (cm) \\
\hline $\begin{array}{l}\text { Precast concrete load-bearing } \\
\text { wall } \\
\text { Alveolar plate slabs + } \\
\text { compression layer } \\
\text { Strip footing }\end{array}$ & $\begin{array}{l}20 \times 300 \times \text { Length } \\
25+5 \times 12 \times \text { Length } \\
140 \times 80 \times \text { Length }\end{array}$ \\
\hline \multicolumn{2}{|l|}{ 4-M-M } \\
\hline Elements & Dimensions (cm) \\
\hline CLT wood load-bearing walls & $16.5 \times 300 \times$ Length \\
\hline CLT wood panel. & $22.5 \times 330 \times$ Length \\
\hline Strip footing & $120 \times 60 \times$ Length \\
\hline \multicolumn{2}{|l|}{ 5-MIX-H } \\
\hline Elements & Dimensions $(\mathrm{cm})$ \\
\hline $\begin{array}{l}\text { Precast concrete Self- } \\
\text { supporting 3D module } \\
\text { Alveolar plate slabs + } \\
\text { compression layer } \\
\text { Pavement }\end{array}$ & $\begin{array}{l}240 \times 326 \times 572 \\
25+5 \times 120 \times \text { Length } \\
30 \times \text { Surface }\end{array}$ \\
\hline \multicolumn{2}{|l|}{ 6-3D-H } \\
\hline Elements & Dimensions (cm) \\
\hline $\begin{array}{l}\text { Precast concrete Self- } \\
\text { supporting 3D module } \\
\text { Wall thickness }\end{array}$ & $\begin{array}{l}450 \times 350 \times 1000 \\
12+15\end{array}$ \\
\hline Pavement & $40 \times$ Surface \\
\hline \multicolumn{2}{|l|}{ 7-3D-M } \\
\hline Elements & Dimensions (cm) \\
\hline $\begin{array}{l}\text { CLT wood self-supporting } 3 D \\
\text { module } \\
\text { CLT wood wall thickness } \\
\text { Foundation slab }\end{array}$ & $\begin{array}{l}450 \times 300 \times 1000 \\
16.5 \text { y } 18 \\
30 \times \text { Surface }\end{array}$ \\
\hline
\end{tabular}

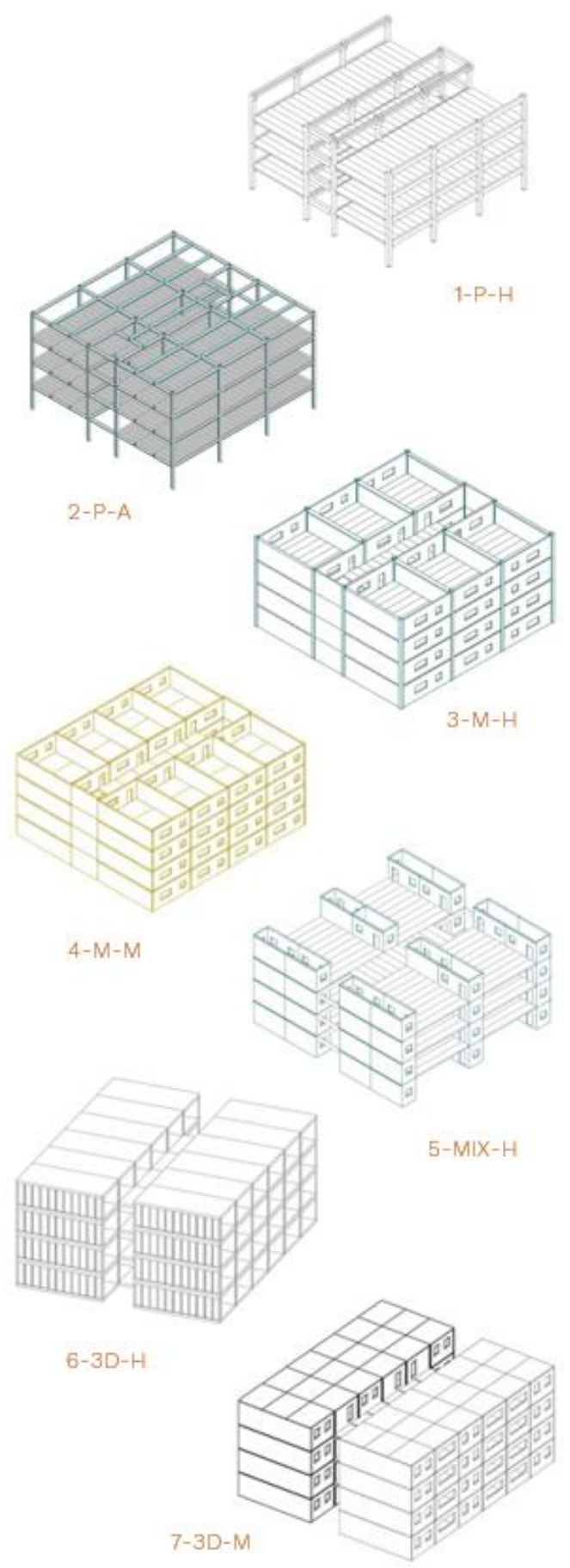

Source: Own ellaboration 


\section{Results}

\subsection{Calculation of environmental impacts by manufacturing}

The results of the impact calculation called EE (Embodied Energy) and EC (Embodied Carbon) which is the Energy and $\mathrm{CO}_{2}$ equivalent for each of the building elements that make up the seven (4-storey) buildings are presented below. (See Table 5, Figure 3, and Figure 4).

Table 5. Area and weight of 7 buildings

\begin{tabular}{|c|c|c|c|c|}
\hline building & construction system & $\begin{array}{l}\text { area } \\
\left(m^{2}\right)\end{array}$ & $\begin{array}{l}\text { weight } \\
\text { (tons) }\end{array}$ & $\begin{array}{c}\text { weight /area } \\
\left(\mathrm{kg} / \mathrm{m}^{2}\right)\end{array}$ \\
\hline $1-\mathrm{F}-\mathrm{C}$ & Precast concrete frames & 2570,40 & 1726,27 & 672 \\
\hline $2-F-S$ & Steel frames & 2590,80 & 1430,24 & 552 \\
\hline $3-W-C$ & Precast concrete walls & 2479,04 & 2391,89 & 965 \\
\hline $4-W-W$ & CLT wood walls & 2728,20 & 898,50 & 329 \\
\hline 5-MIX-C & Precast concrete 3D module and slab & 2621,44 & 1810,06 & 690 \\
\hline $6-3 D-C$ & Precast concrete 3D module & 2548,80 & 3174,27 & 1245 \\
\hline $7-3 D-W$ & CLT wood 3D module & 2592,00 & 1135,54 & 438 \\
\hline
\end{tabular}

Source: Own ellaboration

Figure. 3 Embodied Energy EE (MJ) manufacturing

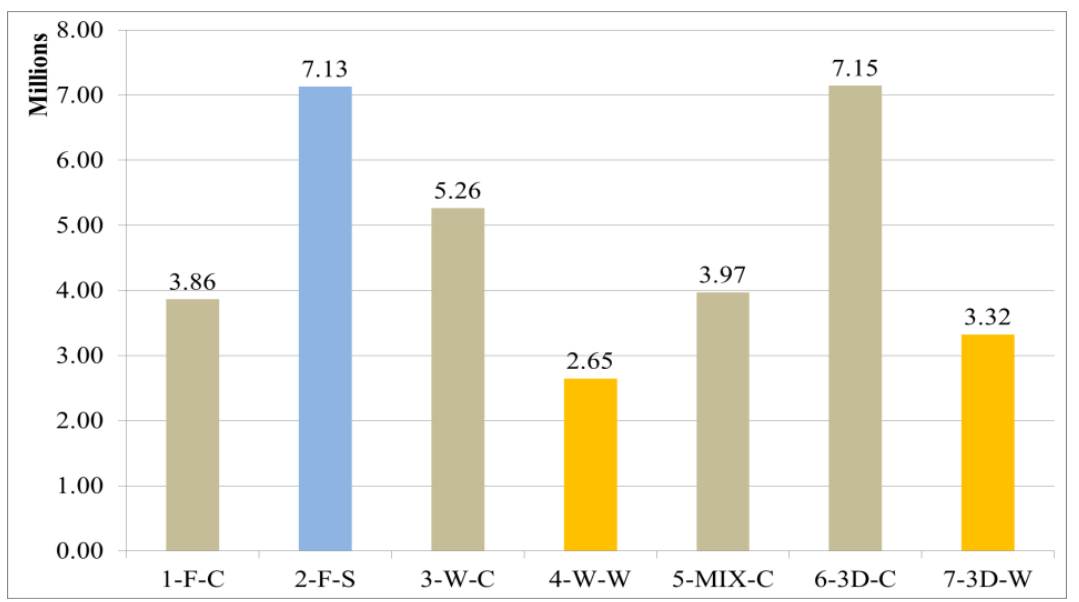

Source: Own ellaboration

Figure 4. Embodied Carbon EC ( $\mathrm{kg} \mathrm{CO} 2$ equivalent) manufacturing

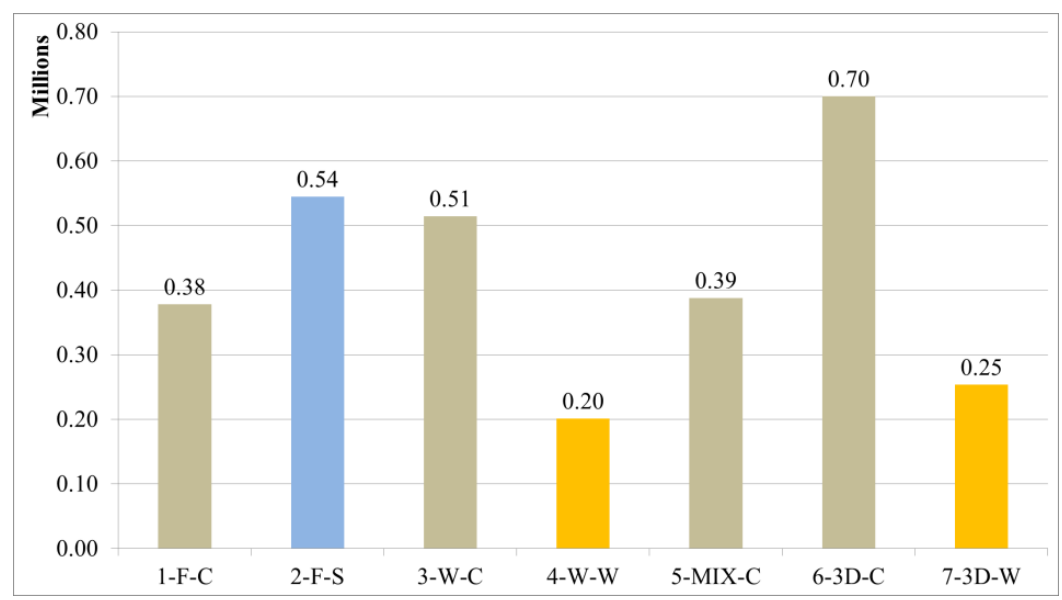

Source: Own ellaboration

ACE, 16 (4.7) CC BY-ND 3.0 ES | UPC Barcelona, España | Embodied Energy and Embodied Carbon in Different Industrialized Structural Systems Scenarios of a Prototype Building. DOI: http://dx.doi.org/10.5821/ace.16.47.104.54 
It can be seen in Figure 5 that the double-axis plot, shows evidence that buildings whose impact is high relative to their weight represent a high environmental impact option, is the case of the 2-P-A steel frame building.

Figure 5. Relation between $\left(\mathrm{kg} / \mathrm{m}^{2}\right)$ and $\left(\mathrm{MJ} / \mathrm{m}^{2}\right)$

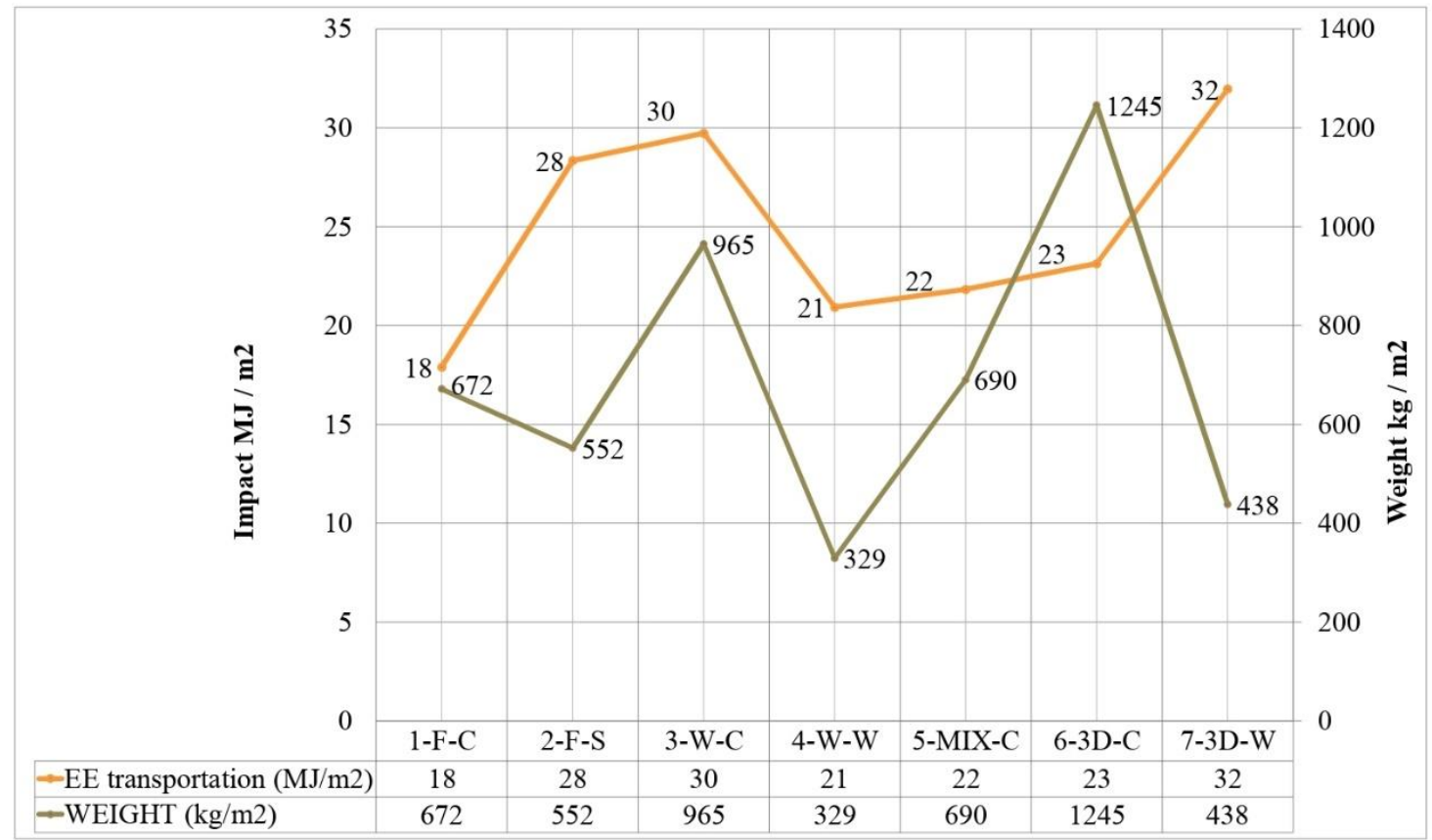

Source: Own ellaboration

\subsection{Calculation of environmental impacts by transportation}

The transport impacts from the factory to the site are estimated for an impact value depending on the type of transport, in this case it has been taken as a sample a 14 tons vehicle for the concrete mixer in-situ for the compression layer, and a 40 tons vehicle for prefabricated and industrialized construction elements.

This data is taken from the consultation of 3 manufacturers in Catalonia. The environmental impact value is endowed according to the type of transport, in this sense, for the vehicle of 14 tons the impact is $0.0022 \mathrm{MJ} / \mathrm{kg} . \mathrm{km}$ and for the 40 tons is $0.0008 \mathrm{MJ} / \mathrm{kg} . \mathrm{km}$ (París Viviana, 2013).

Distance ranges have been determined, from $100 \mathrm{~km}$ for the transport of concrete to be emptied insitu as a parameter deliberately exceeded in order to compare it, since the supply generally does not exceed $25 \mathrm{~km}$. However, for the distances of industrialized prefabrication elements have been taken according to industry location survey and industrialized prefabrication in Spain, being $200 \mathrm{~km}$ for frame elements and concrete walls, $600 \mathrm{~km}$ for steel frame, $800 \mathrm{~km}$ for CLT wooden walls and 1000 $\mathrm{km}$ for 3D wood modules, but in the case of 3D concrete module has been taken as $200 \mathrm{~km}$, since the industry is close to Barcelona where the "prototype- $X$ " building could be hypothetically located (Figure 6).

ACE, 16 (17) CC BY-ND 3.0 ES | UPC Barcelona, España | Embodied Energy and Embodied Carbon in Different Industrialized Structural Systems Scenarios of a Prototype Building. DOI: http://dx.doi.org/10.5821/ace.16.47.10454 


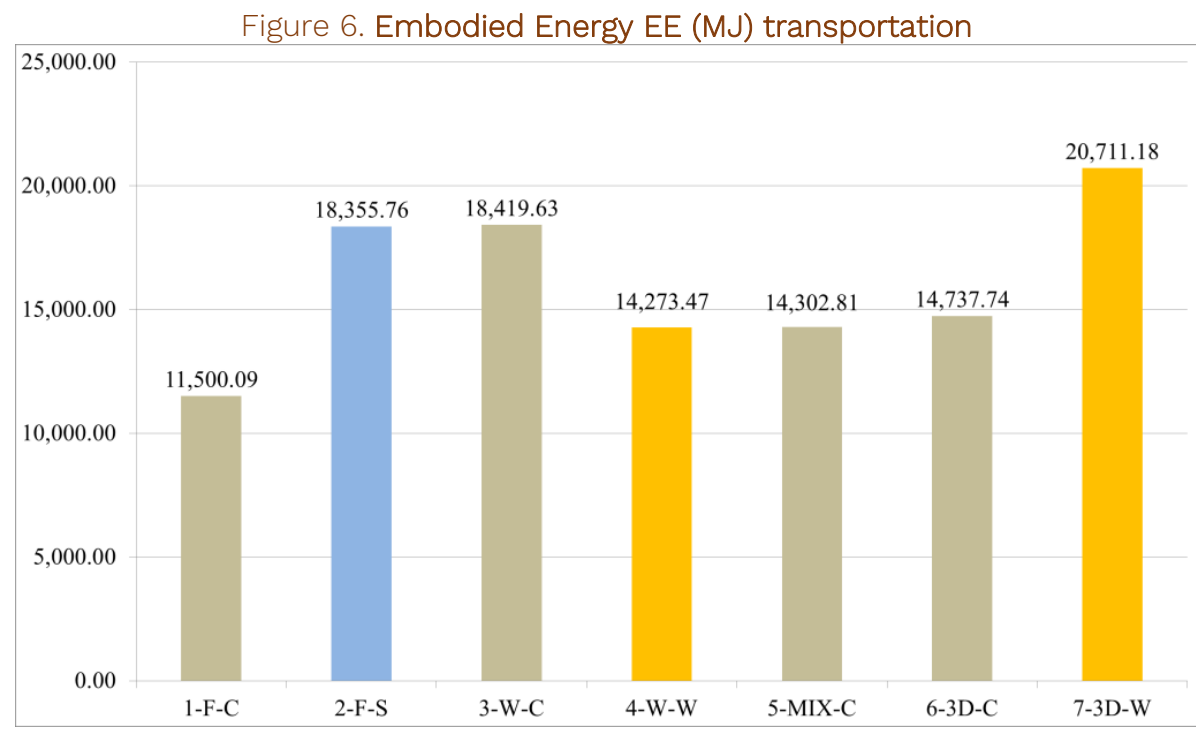

Source: Own ellaboration

Figure 7 shows the transport and manufacturing impacts as well as the comparative relationship between both, with up to 121 times the manufacturing impact being greater than the transport impact, even for building 6-3D-H, which weighs the most.

Figure 7. Relation between EE transportation $\left(\mathrm{MJ} / \mathrm{m}^{2}\right)$ y EE manufacturing $\left(\mathrm{MJ} / \mathrm{m}^{2}\right)$

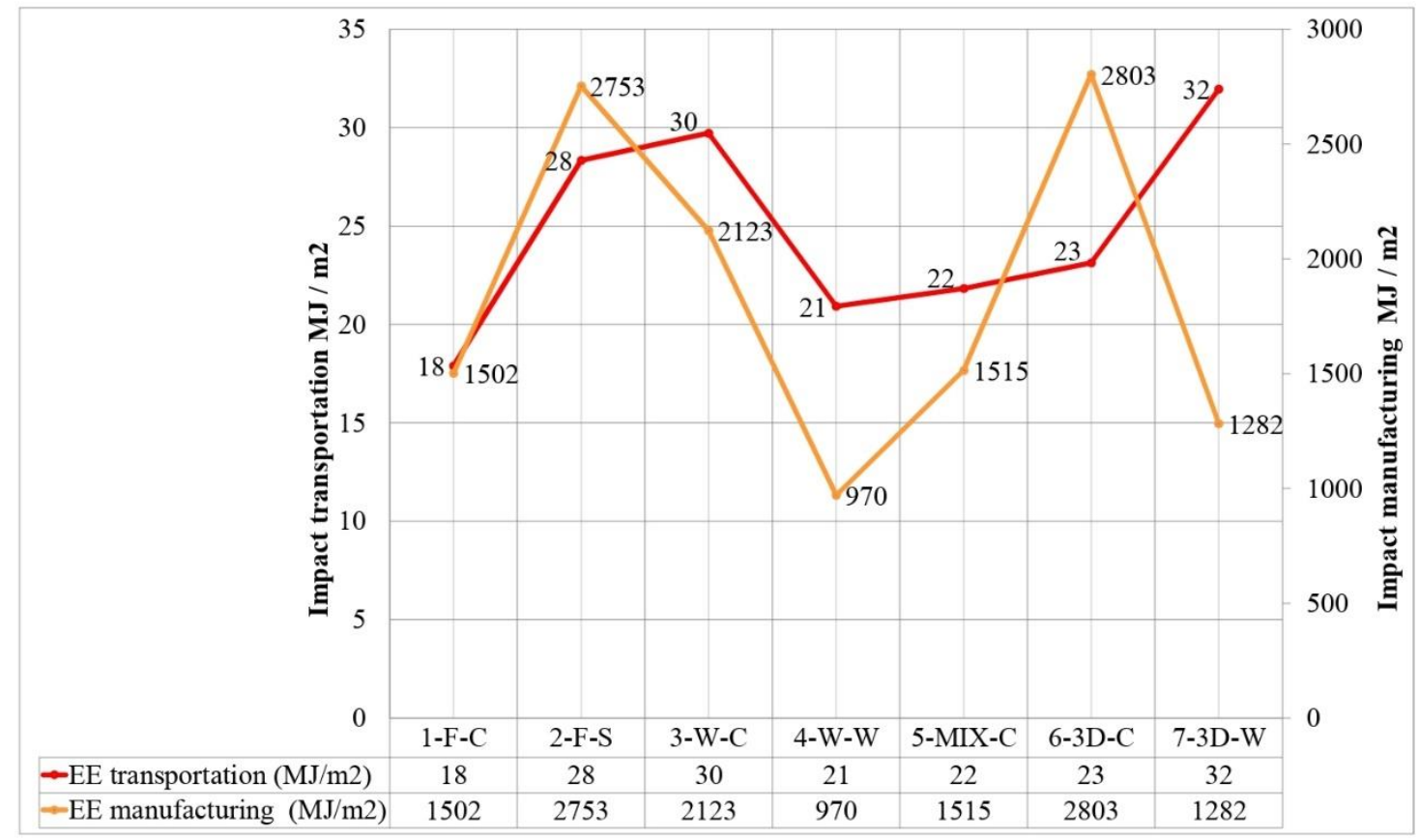

Source: Own ellaboration 


\section{Discussion}

Below are the results of the analysis to establish the potential to avoid impacts, applying 3 concepts (see Figure 8, and Figure 9):

a. Reuse: Process to reuse discarded elements and give them equal or different use (AENOR, 2009). This concept will be applied to avoid impacts, such as the ability of industrialized building elements to maintain their structural function if disassembled and have to be re-assembled, for a second service life (Asam, 2007). The assessment of impacts avoided in the analysis is weighted by five percentages 10, 25, 50, 75, 90 per cent, with 10\% being a low reuse potential that is applied to concrete in-situ and $90 \%$ is applied to those elements with a high reuse potential, to which it is estimated, do not lose their resisting capacity due to the generally articulated bonding type usual in industrialized prefabricated structures.

b. Durability: It is an attribute of the quality of a material, it refers to the time that it remains fulfilling its functions without losing its attributes for what it has been designed for (AENOR, 2009). In order for durability to be maintained over time in structures, the Building Technical Code recommends that maintenance be given at least every 10 years (Ministerio de Fomento, 2007a). In this sense it has been chosen to make a valuation of 0 to 10 years being correlated with the percentage of 0 to 100 percent. Therefore, the longer the maintenance period in number of years, the greater the amount of impacts avoided for durability.

c. Functionability: Practical utility of an element, in a building the functionability can be synonymous with useful area, intended for the function for which it has been created, that is, the spaces served, and with some reserve can be classified as functional spaces the areas intended for circulation and access, leaving outside this classification the area of structures (AENOR, 2009). Therefore, for each building the percentage representing the useful area of the building floor has been obtained, that is, only the housing area and this is the percentage that is valued as an impact avoided, being the largest percentage of area, the greatest impacts avoided. This parameter is also considered as a structural efficiency parameter, due reducing structural elements.

Figure 8. Impacts avoided, comparative analysis Embodied Energy EE (\%)

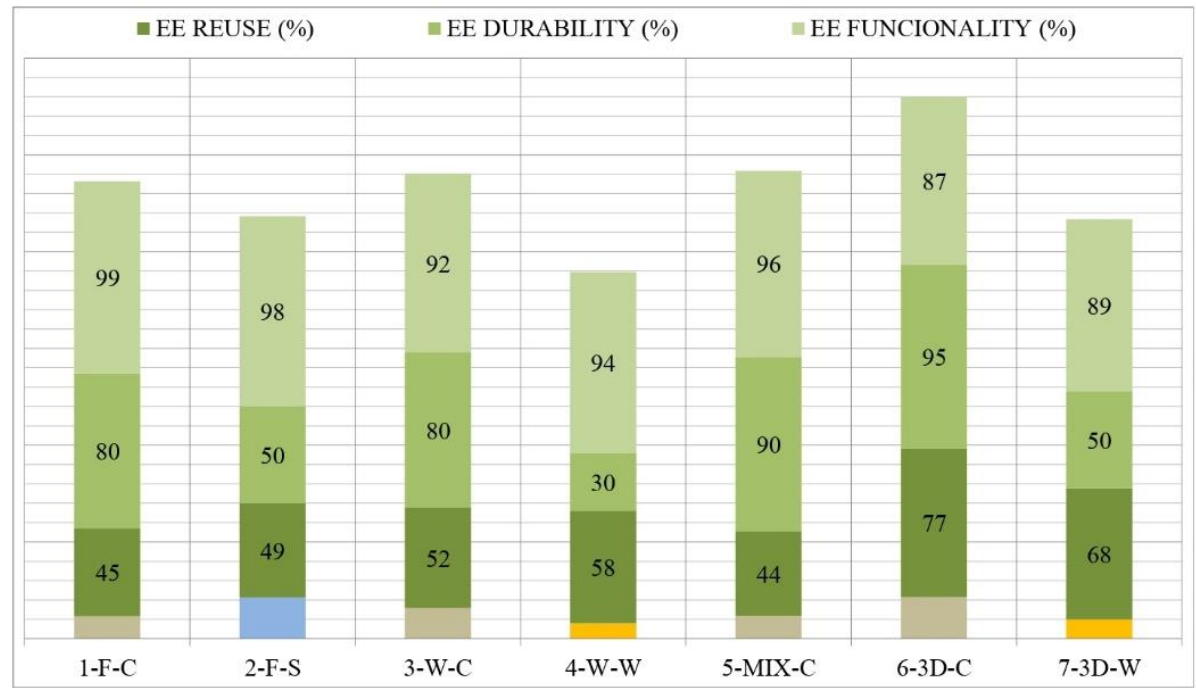

Source: Own ellaboration

ACE, 16 (4.7) CC BY-ND 3.0 ES | UPC Barcelona, España | Embodied Energy and Embodied Carbon in Different Industrialized Structural Systems Scenarios of a Prototype Building. DOI: http://dx.doi.org/10.5821/ace.16.47.10454 
Figure 9. Impacts avoided, comparative analysis Embodied Carbon EC (\%)

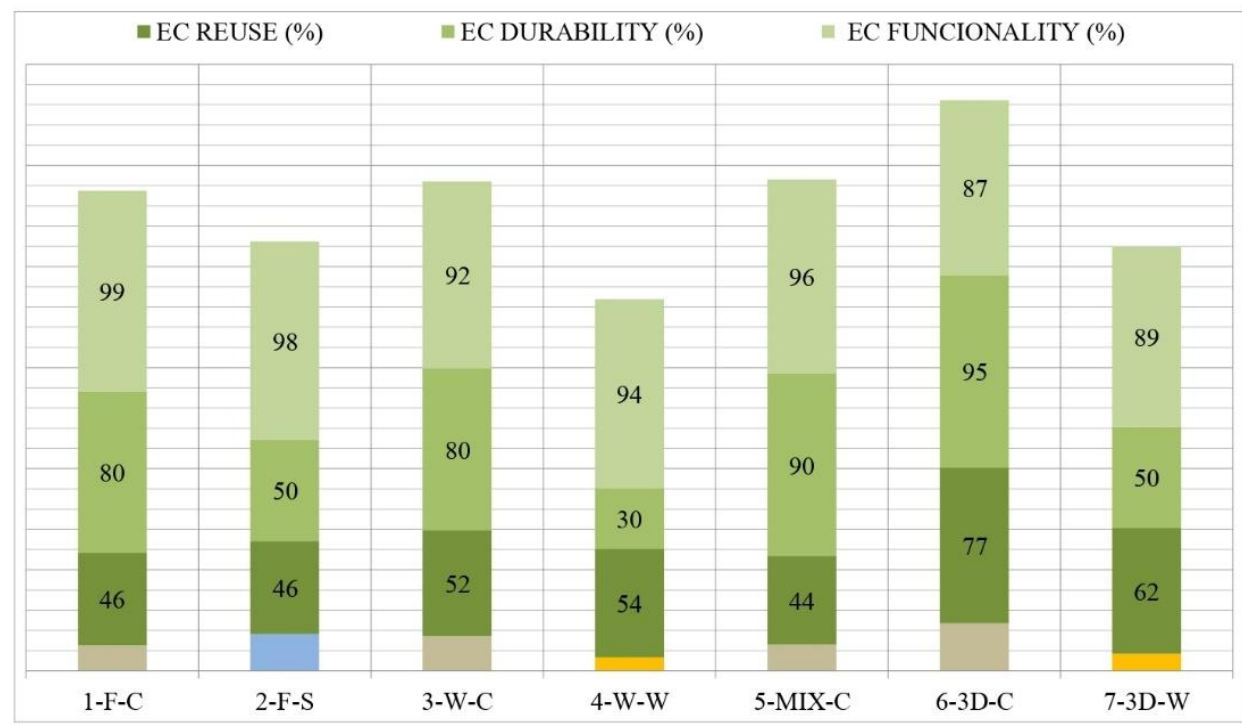

Source: Own ellaboration

\section{Conclusions}

In relation to research phase

1. Industrialized construction has been evolving almost for around a century ago; however, it is not yet affordable to all sectors or in all countries, but the efforts of housing developments that enhance industrialized construction as a strategy of resource optimization and technological development and innovation is noteworthy.

In relation to the development phase

2. The structural preliminary draft and pre-dimensioned in the face of gravitational load, is a representative sample for an evaluation and decision-making in the early stages of a project, but for the decisive stage the entire demanding scenario of the structure is required, which leads the design team to consider hybrid systems between open and closed industrialized manufacturing or between prefabricated systems and in-situ systems.

In relation to the analysis phase

3. The ratios of ICE factors that assess the environmental impact of a material at a given stage of the life cycle are not representative of the impact of a building and is not an indicator of impact superiority, until the assessment is carried out according to the characteristics of the building for example; the ICE factor of laminated steel is $21.5 \mathrm{MJ} / \mathrm{kg}$ against that of precast concrete RC 40-50 $\mathrm{MPa}$ which is $2.33 \mathrm{MJ} / \mathrm{kg}$ being that of steel 9 times that of concrete, however, in the relationship between environmental impacts of buildings there is a ratio of 2 to 1 of steel to concrete in $\mathrm{MJ} / \mathrm{m} 2$. Likewise, the ratio of CLT wood ICE factors is equal to $3.63 \mathrm{MJ} / \mathrm{kg}$ and precast concrete is 1.5 times smaller than that of wood in $\mathrm{MJ} / \mathrm{m} 2$, however the impact ratio of concrete buildings is 2 times greater than wood.

ACE, 16 (4.7) CC BY-ND 3.0 ES | UPC Barcelona, España | Embodied Energy and Embodied Carbon in Different Industrialized Structural Systems Scenarios of a Prototype Building. DOI: http://dx.doi.org/10.5821/ace.16.47.10454 
4. In the impact ratio by manufacturing and transport, manufacturing exceeds up to 75 times more on average transport, assessing distances of up to $1000 \mathrm{~km}$ with buildings weighing up to 3000 tons. 5. Transport is linked to the distance and weight of the elements transported, therefore, when opting for heavy technology it must be done at close range in this case it has been considered $200 \mathrm{~km}$, although on the other hand the low weight ratio, low impact on transport, is evident for wooden buildings, especially in the case of walls, since in the case of 3D wood modules, the volume is synonymous with impact greater than weight, because when transporting the 3D unit it is more air than mass of material that is transported.

6. About the impacts avoided by reuse, less specialized and less fragile elements, in the opposite direction to qualities such as monolithism and robustness, are capable of being reusable up to 50 per cent more than those that are highly specialized.

7. About the impacts avoided by durability, this aspect presents interesting challenges in design philosophies, as the more hyperstatic a structure is the less reusable it is, therefore the challenge is to design the building with sacrificial elements so that others can be recovered and reused.

8. About the impacts avoided by workability the most illustrative case is that of steel porches, since the impacts are considerable, but given its mechanical characteristics, it is the structural system that allows greater flexibility in the design and a more diaphanous plant.

\section{Acknowledgment}

We thank the Central America University UCA in El Salvador. We also thank Professors Jorge Blasco and Albert Albareda for their advice on structural calculation issues of the Polytechnic University of Catalonia, UPC, Spain. The full study can be recovered from: http://hdl.handle.net/2117/166482.

\section{Autorship}

The first author has conceptualized and written the work, and analyzed the data; second author designed the research; third author has analyzed the data; and fourth author has conceptualized the work

Conflict of interests: The authors declare that there is no conflict of interest.

\section{References}

AENOR, A. E. de N. y C. (2006a). Norma UNE-EN 14040:2006. Gestión ambiental. Análisis del ciclo de vida. Principios y marco de referencia. (ISO 14040:2006).

AENOR, A. E. de N. y C. (2006b). Norma UNE-EN 14044:2006. Gestión ambiental. Análisis del ciclo de vida. Requisitos y directrices. (ISO 14044:2006).

AENOR, A. E. de N. y C. (2009). UNE 41805-1-2009 IN Diagnóstico de edificios. Parte 1: Generalidades. AENOR, A. E. de N. y C. (2014). Norma UNE-EN 15804:2012+A1. Sostenibilidad en la construcción. Declaraciones ambientales de producto. Reglas de categoría de producto básicas para productos de construcción. Norma Española versión de Norma Europea UNE-EN 15804:2012.

Albus, J. (2017). Prefabrication Concepts in Residential Construction: The Benefits of Modular and Unitized Construction Methods Based on Lightweight and Solid Material Utilization. Annual International Conference on Architecture, 393.

Albus, J. (2018). Prefabricated housing: construction and design manual. Berlin: DOM publishers.

ACE, 16 (4.7) CC BY-ND 3.0 ES | UPC Barcelona, España | Embodied Energy and Embodied Carbon in Different Industrialized Structural Systems Scenarios of a Prototype Building. DOI: http://dx.doi.org/10.5821/ace.16.47.10454 
Asam, C. (2007). Recycling prefabricated concrete components-a contribution to sustainable construction. Institute for Preservation and Modernisation of Buildings, Technical University of Berlin, Berlin, Germany, IEMB Info, 3, 2007.

Asociación Técnica Española del Pretensado (FIP-ATEP). (1996). Estructuras de edificación prefabricadas.

Chau, C. K., Leung, T. M., \& Ng, W. Y. (2015). A review on life cycle assessment, life cycle energy assessment and life cycle carbon emissions assessment on buildings. Applied Energy, 143(1), 395-413. https://doi.org/10.1016/j.apenergy.2015.01.023

Chemillier, P. (1980). Industrialización de la construcción (Primera; E. T. A. Reverte, Ed.). Barcelona.

Comunidad Autónoma de Cataluña. (2017). Ley 16/2017 del Cambio Climático. DOGC No 7426, BOE No234 Legislación Consolidada referencia BOE A-2017-11001.

Eberhardt, L. C. M., Birgisdóttir, H., \& Birkved, M. (2019). Life cycle assessment of a Danish office building designed for disassembly. Building Research and Information, 476), 666-680. https://doi.org/10.1080/09613218.2018.1517458

European Commission. (2021). Level(s) A common EU framework of core sustainability indicators for office and residential buildings. European Commission Joint Research Centre.

Flager, F., Lepech, M., \& Fischer, M. (2013). Application of life-cycle assessment to early stage building design for reduced embodied environmental impacts. Building and Environment, 60, 81-92. https://doi.org/10.1016/j.buildenv.2012.11.009

Hammond, G., Jones, C., Lowrie, E. F., \& Tse, P. (2011). Embodied carbon. The Inventory of Carbon and Energy (ICE). Version (2.0).

Hammond, G. P., \& Jones, C. I. (2008). Embodied energy and carbon in construction materials. Proceedings of the Institution of Civil Engineers - Energy, 161(2), 87-98. https://doi.org/10.1680/ener.2008.161.2.87

Hollberg, A., Genova, G., \& Habert, G. (2020). Evaluation of BIM-based LCA results for building design. Automation in Construction, 109. https://doi.org/10.1016/j.autcon.2019.102972

Ministerio de Fomento, G. de E. (2007a). CTE-DB-SE-A. Código Técnico de la Edificación, Documento Básico de Seguridad Estructural, Acero.

Ministerio de Fomento, G. de E. (2007b). CTE-DB-SE-C. Código Técnico de la Edificación, Documento Básico de Seguridad Estructural, Cimientos.

Ministerio de Fomento, G. de E. (2009a). CTE-DB-SE-AE. Código Técnico de la Edificación, Documento Básico de Seguridad Estructural, Acciones en la Edificación.

Ministerio de Fomento, G. de E. (2009b). CTE-DB-SE-M. [10] Código Técnico de la Edificación, Documento Básico de Seguridad Estructural, Madera, CTE-DB-SE-M.

Ministerio de Fomento, G. de E. (2009c). CTE-DB-SE. Código Técnico de la Edificación, Documento Básico de Seguridad Estructural.

París Viviana, O. (2013). La "clientalización" de los sistemas industrializados de fachada. Una estategia de producción para la "clientalización" de la forma de los componentes planos de hormigón. Universitat Politècnica de Catalunya, 2013.

Pons, O., \& Wadel, G. (2011). Environmental impacts of prefabricated school buildings in Catalonia. Habitat International, 35(4), 553-563. https://doi.org/2011.03.005

Rossi, B., Marique, A. F., Glaumann, M., \& Reiter, S. (2012). Life-cycle assessment of residential buildings in three different European locations, basic tool. Building and Environment, 51, 395-401. https://doi.org/10.1016/j.buildenv.2011.11.017

ACE, 16 (4.7) CC BY-ND 3.0 ES | UPC Barcelona, España | Embodied Energy and Embodied Carbon in Different Industrialized Structural Systems Scenarios of a Prototype Building. DOI: http://dx.doi.org/10.5821/ace.16.47.10454 